\title{
PENGARUH PROMOSI TENAGA KESEHATAN TERHADAP PENINGKATAN PEMBERIAN IMUNISASI CAMPAK RUBELLA DI PUSKEMAS BANDAR KHALIPAH TAHUN 2019
}

\author{
Mestika Rija Helti ${ }^{1}$, Suriani ${ }^{2}$, Zakiah $^{3}$
}

STIKes Rumah Sakit Haji Medan, Indonesia

\section{Article Info}

\section{Keywords:}

Promotion

Rubella Measles

Total Coverage

\begin{abstract}
Measles and rubella can have a negative impact on children's health in Indonesia, so the government has implemented an MR vaccination campaign (MMR VIS - Indonesia, 2012). The MR (Measles Rubella) vaccine provides benefits such as protecting children from disability and death due to complications of pneumonia, diarrhea, brain damage, deafness, blindness and congenital heart disease. There were 83 confirmed cases of CRS in 2015-2016 of which 77\% suffered from heart defects, $67.5 \%$ suffered from cataracts and $47 \%$ suffered from deafness (Ditjen P2P, 2016). The research objective was the Effect of Promotion of Health Workers on the Improvement of Rubella Measles Immunization at the Bandar Khalipah Public Health Center in 2019. This type of research is descriptive analytic with a cross sectional approach with a sample size of 18 , it is recommended to carry out promotions. The sampling technique is purposive sampling technique. The research instrument uses leaflet sheets. Univariate analysis using Microsoft Excel. The results showed that the total coverage of rubella measles immunization prior to promotion at the Bandar khalipah health center 2019 was $340(7.8 \%)$ in the "decreased" category and after promotion the total coverage of rubella measles immunization at the Bandar khalipah puskesmas was $367(8.6 \%)$ are in the "increasing" category. So that there is an effect of promotion of health workers on increasing the provision of rubella measles immunization at the Bandar khalipah public health center in 2019. Conclusion in this study there is an effect of promotion of health workers on increasing rubella measles immunization, so that health workers can use promotion as an effort to support government programs, coverage of immunization rubella measles $95 \%$.
\end{abstract}

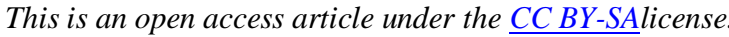

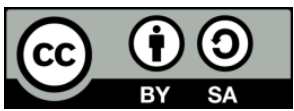

\section{Corresponding Author:}

Mestika Rija Helti,

Program Studi D-III Kebidanan,

STIKes Rumah Sakit Haji Medan,

Jl. Rumah Sakit H., Medan Estate, Kec. Percut Sei Tuan, Kabupaten Deli Serdang, Medan -Sumatera Utara. Email: mstikahelti@gmail.com 


\section{INTRODUCTION}

Campak dan Rubella merupakan penyakit infeksi menular melalui saluran nafas yang disebabkan oleh virus Campak dan Rubella (IDAI, 2017). Batuk dan bersin dapat menjadi jalur masuknya virus campak maupun rubella (WHO, 2017). Campak merupakan penyakit menular yang disebabkan oleh virus genus Morbillivirus (Kutty, et al., 2013).

WHO (World Health Organization) Tahun 2011, menyatakan bahwa mereka mendukung sepenuhnya penggunaan imunisasi MR (Measles, Rubella) dengan didasarkan kajian tentang keamanan dan identifikasinya (Maulana, 2009). Amerika Serikat telah merekomendasikan penggunaan kombinasi vaksin MR (Measles, Rubella) dengan vaksi varisela Sejak september 2005. Dari laporan Center For Disease Control (CDC) di dapatkan bahwa penggunaan vaksin kombinasi MR (Measles, Rubella) dengan varisela cukup aman, tidak didapatkan efek samping yang berarti. Oleh karena itu, Center For Disease Control (CDC) merekomendasikan bahwa kombinasi vaksin MR (Measles, Rubella) dan vaksin varisela dapat diberikan sebagai dosis awal pemberian imunisasi pada kelompok usia 12-47 bulan (WHO, 2011 ).

Penyebab Rubella adalah togavirus jenis rubivirus dan termasuk golongan virus RNA. Virus dapat berkembang biak di nasofaring dan kelenjar getah bening regional, dan viremia terjadi pada 4-7 hari setelah virus masuk tubuh. Virus tersebut dapat melalui sawar plasenta sehingga menginfeksi janin dan dapat mengakibatkan abortus atau Congenital Rubella Syndrome/CRS. Masa penularan diperkirakan terjadi pada 7 hari sebelum hingga 7 hari setelah rash. Masa inkubasi Rubella berkisar antara 14-21 hari. Gejala Rubella ditandai dengan demam $\left(37,2^{\circ} \mathrm{C}\right)$ dan bercak merah/rash makulopapuler disertai pembesaran kelenjar limfe di belakang telinga, leher belakang dan sub occipital (Ditjen P2P, 2018).

Rubella merupakan masalah kesehatan yang mempunyai berbagai dampak klinis dan dapat memberikan dampak buruk baik berupa mortalitas dan morbiditas (Nazme, et al., 2014). Rubella termasuk dalam penyakit ringan pada anak, tetapi dapat memberikan dampak buruk apabila terjadi pada ibu hamil trimester pertama yaitu keguguran ataupun kecacatan pada bayi sering disebut Congenital Rubella Syndrom (CRS) seperti kelainan jantung dan mata, ketulian dan keterlambatan perkembangan (Depkes RI, 2017).

Penyakit campak dan rubella dapat memberikan dampak buruk terhadap kesehatan anak di Indonesia, sehingga pemerintah melaksanakan kampanye vaksinasi MR (MMR VIS - Indonesia, 2012). Pemberian imunisasi MR pada usia 9 bulan sampai dengan $<15$ tahun dengan cakupan tinggi (minimal 95\%) dan merata diharapkan akan membentuk kelompok (Herd Community), sehingga dapat mengurangi transmisi virus ke usia yang lebih dewasa dan melindungi kelompok tersebut ketika memasuki usia reproduksi. Vaksin MR (Measles Rubella) memberikan manfaat seperti dapat melindungi anak dari kecacatan dan kematian akibat komplikasi pneumonia, diare, kerusakan otak, ketulian, kebutaan dan penyakit jantung bawaan (Ditjen P2P, 2018).

Pada tahun 2010 sampai 2015, terdapat 23.164 kasus campak dan 30.463 kasus rubella di Indonesia (Ditjen P2P, 2016). Incidence Rate Campak per 100.000 penduduk di Indonesia pada tahun 2011-2017 menunjukkan kecendrungan penurunan, dari 9,2 menjadi 5,6 per 100.000 penduduk. Namun demikian, incidence rate cenderung naik dari tahun 2015 sampai dengan 2017, yaitu dari 3,2 menjadi 5,6 per 100.000 penduduk (Ditjen P2P, 2018).

Kasus campak tertinggi menurut Provinsi adalah Jawa Timur (3.547) yang divaksinasi 1.337 (38\% yang diberikan vaksin), DI Yogyakarta (1.067) yang di vaksinasi 278 (26\% yang diberi vaksin) dan Sumatra Utara (232) yang divaksinasi 46 (19\% yang diberi vaksin) (Profil Kesehatan RI, 2017). Terlihat jelas bahwa penyebab jumlah kasus campak yang terdapat di provinsi Sumatra utara disebabkan karena tidak diberikan vaksin, yaitu hanya hanya $19 \%$ yang mendapatkan vaksin.

Berdasarkan Data yang diperoleh di Kabupaten Deli Serdang jumlah cakupan bayi yang mendapatkan Imunisasi Campak Rubella pada tahun 2018 adalah 58,62\% bayi yang mendapatkan imunisasi campak rubella sehingga disimpulkan bahwa cakupan imunisasi campak rubella belum mencapai $100 \%$. (Profil Puskesmas Bandar Khalifah, 2019 ).

Berdasarkan Data yang diperoleh dipuskesmas Bandar Khalipah jumlah sasaran bayi mendapatkan Imunisasi Campak Rubella adalah 4.272. Bayi yang mendapatkan imunisasi campak rubella adalah 355 dengan komulatif $25 \%$. Sehingga disimpulkan bahwa cakupan imunisasi campak rubella belum mencapai 100\% (Profil Puskesmas Bandar Khalifah, 2019).

Vaksin MR merupakan vaksin hidup yang sudah dilemahkan dalam bentuk serbuk dan pelarutnya. Vaksin MR diberikan pada anak usia 9 bulan sampai dengan 15 tahun (Ditjen P2P, 2016). Millenium Development Goal 4 mempunyai tujuan khusus yaitu mengurangi angka kematian bayi dibawah usia 5 tahun (McGee, 2013).

Terdapat beberapa kelompok yang termasuk antivaksin, umumnya mengabaikan pencegahan penyakit dan hanya mengutamakan kuratif. Ada beberapa faktor yang menjadi alasan adanya kelompok antivaksin diantaranya persepsi mengenai proses pembuatan vaksin yang mengandung babi dan vaksin tanpa sertifikat halal. Kedua hal tersebut menimbulkan persepsi masyarakat terhadap imunisasi (IDAI, 2015). 
Bidan berperan penting dalam pemberian imunisasi terhadap masyarakat, ada beberapa faktor yang dapat mempengaruhi diantaranya pengetahuan tentang vaksinasi dan pendidikan bidan (Senewe, et al., 2017).

Informasi adalah data yang yang diproses atau diolah menjadi bentuk yang berguna dan berarti bagi penerimanya (Jr, Raymod, \& Schell, 2008). Fungsi utama dari informasi adalah menambah pengetahuan (Hutahaean, 2015). Media promosi kesehatan adalah informasi atau pesan yang dapat disampaikan melalui media cetak, elektronika, dan media luar ruang, sehingga dapat meningkatkan pengetahuan dan berubahnya perilaku kesehatan ke arah positif (Notoatmodjo, 2012). Menurut (Wibawati, 2014) dalam promosi kesehatan ada hambatan dalam penyebaran informasi melalui media promosi kesehatan, yaitu keterbatasan dana puskesmas dalam menyediakan media pendukung seperti video dan media cetak mengenai informasi kesehatan. Informasi yang lengkap tentang vaksin MR akan mendorong orang untuk ikut serta imunisasi (Notoatmodjo, 2012).

Berdasarkan deskripsi di atas, penulis tertarik untuk melakukan penelitian mengenai Pengaruh Promosi Tenaga Kesehatan Terhadap Peningkatan Pemberian Imunisasi Campak Rubella di Puskesmas Bandar Khalipah Kabupaten Deli Serdang Tahun 2019. Tujuan Umum Penelitian untuk Mengetahui Pengaruh Promosi Tenaga Kesehatan Terhadap Peningkatan Pemberian Imunisasi Campak Rubella di Puskesmas Bandar Khalipah Kabupaten Deli Serdang Tahun 2019. Tujuan Khusus Penelitian Untuk Mengetahui Jumlah Target Imunisasi Puskesmas Bandar Khalipah dan Untuk Mengetahui Jumlah Cakupan Imunisasi Sebelum dan Sesudah Promosi Tenaga Kesehatan.

Manfaat Penelitian bagi Responden adalah Sebagai tambahan pengetahuan tenaga kesehatan tentang pentingnya pemberian imunisasi campak rubella. Manfaat penelitian bagi tempat praktek Sebagai informasi dan tambahan pengetahuan bagi tenaga kesehatan yang bekerja di wilayah kerja puskesmas Bandar Khalipah. Manfaat penelitian bagi peneliti selanjutnya Sebagai sumber informasi dan bahan bacaan untuk proses pembelajaran, bahan referensi di perpustakaan, dan dapat menjadi masukan bagi mahasiswa/i Sekolah Tinggi Ilmu Kesehatan Rumah Sakit Haji Medan khususnya tentang Imunisasi Campak Rubella.

\section{RESEARCH METHOD}

Penelitian ini akan menggunakan jenis deskriptif analitik yang bersifat survey, yang mana data diperoleh dengan melakukan survey ke tempat objek penelitian. Penelitian analitik merupakan penelitian atau penelaah hubungan antara variabel independen dan variabel dependen yaitu ingin melihat Pengaruh Promosi Tenaga Kesehatan Terhadap Peningkatan Pemberian Imunisasi Campak Rubella Di Puskesmas Bandar Khalipah Tahun 2019.

\section{RESULTS AND ANALYSIS}

3.1 Hasil

\section{Analisi Univariat}

Tabel 1. Distribusi Frekunsi Jumlah Cakupan Pemberian Imunisasi Campak Rubella Sebelum dan Sesudah Dilakukan Promosi di Puskesmas Bandar Khalipah 2019

\begin{tabular}{cccccc}
\hline Kategoti & F & \% & f Komulatif & \% Komulatif & Keterangan \\
\hline Pre Promosi & 340 & 7,8 & 340 & 7,8 & Menurun \\
\hline Post Promosi & 367 & 8,6 & 707 & 16,4 & Meningkat \\
\hline
\end{tabular}

Tabel 1 di atas menunjukkan bahwa jumlah cakupan pemberian imunisasi campak rubella sebelum dilakukan promosi di Puskesmas Bandar khalipah 2019 adalah 340 (7,8\%) dalam kategori "menurun" dan setelah dilakukan promosi jumlah cakupan pemberian imunisasi campak rubella di puskesmas Bandar khalipah adalah $367(8,6 \%)$ dalam kategori “meningkat”.

\subsection{Pembahasan}

Jumlah cakupan imunisasi campak rubella sebelum dan sesudah dilakukan promosi tentang imunisasi campak rubella. Berdasarkan penelitian yang telah dilakukan di Puskesmas Bandar Khalipah ahun 2019 didapatkan bahwa jumlah cakupan pemberian imunisasi campak rubella sebelum dilakukan promosi di Puskesmas Bandar khalipah 2019 adalah 340 (7,8\%) dalam kategori "menurun" dan setelah dilakukan promosi jumlah cakupan pemberian imunisasi campak rubella di puskesmas Bandar khalipah adalah 367 $(8,6 \%)$ dalam kategori "meningkat".

Imunisasi adalah suatu upaya untuk menimbulkan atau meningkatkan kekebalan seseorang terhadap suatu penyakit tertentu, sehingga bila suatu saat terpapar dengan penyakit tersebut tidak akan sakit atau hanya mengalami sakit ringan. Beberapa penyakit menular yang termasuk ke dalam Penyakit yang Dapat Dicegah dengan Imunisasi (PD3I). Program imunisasi merupakan salah satu upaya untuk memberikan perlindungan terhadap penyakit tertentu (Depkes, 2016).

Program imunisasi telah menunjukkan keberhasilan yang luar biasa dan merupakan usaha yang sangat hemat biaya dalam mencegah penyakit menular. Imunisasi juga telah berhasil menyelamatkan begitu 
banyak kehidupan dibandingkan dengan upaya kesehatan masyarakat lainnya (Bankes, 2013). Hasil penelitian ini sejalan dengan teori yang menyebutkan bahwa jahe yang diekstraksi cukup efektif menghilangkan radang dan nyeri ringan hingga sedang (Hawarti, 2010).

Selain masalah kehalalan vaksin dan adanya KIPI, vaksin rusak dan vaksin palsu merupakan isu yang dikhawatirkan akan menjadi kontroversi di tengah masyarakat. Sebagai produk biologi yang mudah rusak, vaksin harus disimpan pada suhu antara 2 hingga $8^{\circ} \mathrm{C}$. Dari mulai produksi hingga konsumsi harus memperhatikan manajemen rantai dingin. Menjadi tanggung jawab pemerintah pusat dan daerah untuk menjamin kelengkapan logistik seperti peralatan cold chain, safety box, alat suntik dan lainnya. Ketersediaan rantai dingin menjadi kendala di daerah karena belum semua fasilitas pelayanan kesehatan (fasyankes) memiliki sarana rantai dingin. Selain mengantisipasi vaksin rusak, juga perlu diantisipasi munculnya kasus vaksin palsu. Saat ini, BUMN yang ditunjuk pemerintah untuk memenuhi kebutuhan imunisasi campakrubela adalah PT Biofarma. Perusahaan tersebut mengimpor 47,7 juta dosis dari India. Tingginya permintaan vaksin MR dapat menjadi peluang bagi pihak tertentu untuk memproduksi dan menjual vaksin palsu. Terlebih vaksin serupa (MMR) pernah mengalami kekosongan stok.

Campak dan Rubella merupakan penyakit yang sangat menular. Anak-anak dan orang dewasa yang belum pernah diimunisasi Campak dan Rubella, atau yang belum pernah mengalami penyakit Campak dan Rubella memiliki risiko tinggi tertular penyakit ini. Hasil penelitian ini sesuai dengan hasil penelitian yang dilakukan oleh (Rika Rianti, 2015) tentang Faktor-Faktor Yang Mempengaruhi Pemberian Imunisasi Dasar Pada Bayi Di Wiayah Kerja Puskesmas Paal V Kota Jambi Tahun 2015 didapatkan hasil bahwa sebanyak 72 responden $(87,8 \%)$ mempunyai peran tenaga kesehatan baik dan 10 responden $(12,2 \%)$ mempunyai dukungan keluarga negatif. Hasil dari penelitian ini selaras dengan penelitian (Dewi, 2017) yang menjelaskan bahwa persepsi manfaat yang dirasakan ibu secara signifikan berhubungan dengan status imunisasi anak.

\section{CONCLUSION}

1. Jumlah cakupan imunisasi campak rubella di puskesmas Bandar khalipah sebelum dilakukan promosi adalah $340(7,8 \%)$ dalam kategori "menurun".

2. Jumlah cakupan imunisasi campak rubella di wilayah kerja Puskesmas Bandar Khalipah setelah dilakukan promosi adalah 367 (8,6\%) dalam kategori "meningkat".

3. Promosi tenaga kesehatan tentang imunisasi campak rubella yang dilakukan di Puskesmas Bandar Khalipah dapat meningkatkan jumlah cakupan pemberian imunisasi campak rubella.

\section{REFERENCES}

Ambarwati, Retna 2017. Asuhan Kebidanan Komunitas. Yogyakarta: Nuha Medika.

Arikunto, S. 2014. Prosedur Penelitian: Suatu Pendekatan Praktik. Jakarta: Rineka Cipta.

Astuti Widhi 2016. Konsep Kebidanan Dan Etikolegal Dalam Praktik Kebidanan. Bandung: Bina pustaka.

Catatan Iptek: Imunisasi”, Kompas, 23 Agustus 2017, hlm. 14.

Damaiyanti. 2017. Asuhan Kebidanan Komunitas. Bandung : PT Refika Aditama.

Fobia Rubela", Kompas, 27 Juli 2017, hlm.7.

Heryani, Reni. 2016. Asuhan Kebidanan Komunitas. Jakarta: CV. Trans InfoMedia.

Imunisasi Campak Rubella: Mencegah Tetap Lebih Baik", Kompas, 12 Agustus 2017, hlm. 14.

Imunisasi Campak-Rubella: SosialisasiPerlu Ditingkatkan”, Kompas, 1 Agustus 2017, hlm. 14

Kementerian Kesehatan. (2016). Profil Kesehatan Indonesia 2015. Jakarta:Kementerian Kesehatan.

Mangkuji, Betty, dkk. 2012. Asuhan Kebidanan 7 Langkah SOAP. Jakarta: EGC

Sarwono. P. Ilmu kebidanan. Jakarta. Bina pustaka.

Notoatmodjo, S. 2012. Metedologi Penelitian Kesehatan. Jakarta: Rineka Cipta.

Nursalam. 2013. Konsep Penerapan Metode Penelitian Ilmu Keperawatan. Jakarta: Salemba Medika.

Perry, AG., dan Potter, P.A. 2010. Buku Ajar Fundamental Keperawatan Edisi ketujuh, buku ketiga. Jakarta: EGC.

Profil kesehatan Puskesmas Bandar Khalipah kabupaten deli serdang (diakses: januari-maret 2019).

Prawira. B. Jumlah Perokok Di Indonesia Meroket. 2011. Di Ambil Pada 28 Desember 2015. Dari http://nad.bkkbn.go.id/berita/423/.

Sujarweni, V. Wiratna. 2014. Metode Penelitian: Lengkap, Praktis, dan Mudah Dipahami. Yogyakarta: Pustaka Baru Press.

Kementrian Kesehatan Republik Indonesia. Penyakit Tidak Menular. Bulletin.

Nursalam. 2018. Konsep dan Penerapan Metodologi Penelitian Ilmu Keperawatan. Jakarta: Salemba Medika.

Sugiyono. Metode Penelitian Kuantitatif, Kualitatif dan R \& D. Bandung: Alfabeta. 2014. 